\title{
Falls and health-related quality of life (SF-36) in elderly people-ISACAMP 2008
}

\author{
lara Guimarães Rodrigues*, Margareth Guimarães Lima, Marilisa Berti de Azevedo Barros
}

Faculty of Medical Sciences, Department of Public Health, State University of Campinas, Campinas, Brazil;

*Corresponding Author: iaraguimar@gmail.com

Received 23 October 2013; revised 25 November 2013; accepted 2 December 2013

Copyright (C) 2013 Iara Guimarães Rodrigues et al. This is an open access article distributed under the Creative Commons Attribution License, which permits unrestricted use, distribution, and reproduction in any medium, provided the original work is properly cited.

\section{ABSTRACT}

Falls are accidental events and harmful to the healthy elderly. Its consequence can lead to the disability and the death. Accordingly, it becomes important to assess the relation between falls and quality of life. This theme is little studied in Brazil and internationally, especially in areas with large population bases. Objective: To identify the association between occurrence of fall and health-related quality of life (HRQL) using the SF-36 according to gender, age and schooling, among the elderly population of Campinas/Brazil. Methods: A cross-sectional, population-based study, using data from ISACAMP 2008. The present study analyzed only the population with 60 years old or more, totaling 1432 elderly individuals. The dependent variables were the eight SF-36 scale, version 2. The main independent variables were the falls occurred in the last 12 months and the limitation in activities daily living due to the falls. Analysis were carried out with the simple and multiple linear regression model in order to determine the associations between the dependent and main independent variables, using svy commands of STATA 11.0. Results: The prevalence of falls in the last year was $6.3 \%$. The elderly individuals who referred to fall in the last 12 months exhibited the lowest score in seven of eight SF-36 scales, comparing with non-fallers. The association between fall and HRQL was greater in the male population. The elderly individuals who are older (75 or more) and located in the lower schooling stratum, and experienced falls also exhibited the lowest SF-36 scale scores, in physical and social functioning. Stratifying falls, considering those who cause limitations and those who do not, can be observed with the lowest scores in physical functioning, role physical, role emotion and social functioning, and only in the stratum of people who have limitations in daily living. Conclusion: The occurrence of falls can cause important limitations in the elderly individuals, and the limitations are associated with the worst health condition and quality of life. It is important to consider that the fragile elderly, especially in physical, social functioning, with pain, and role physical, are most vulnerable to experience falls, principally those who cause limitation.

Keywords: Falls; Elderly; Quality of Life

\section{INTRODUCTION}

According to the projections from the WHO (World Health Organization), the period from 1975 to 2025 will be the ageing era. The elderly population in Brazil, following the worldwide population ageing trend, will grow 16 times. Thereby, the country will have the sixth elderly largest population of the world in absolute terms [1], that is, in the next decades a deep change will be generated in the configuration of the Brazilian population.

The elderly are facing problems such as the concomitant ageing process and the increasing health problems, including the incidence of falls, which can cause declines in mental and social health of the elderly, serious injury, functional disability, dependence for carrying out usual activities, hospitalization and death [2].

The fall is an accidental event, which occurs due to the loss of postural balance, probably due to the sudden failure of neural and osteoarticular mechanisms involved in the maintenance of posture [3]. Researches have revealed that the occurrence of falls is higher among older women, older aged widowed individuals with low education and those who use many medications [4,5]. Elderly people with visual alterations, gait and balance disorders, as well 
as those having a higher number of associated diseases, are also most affected by falls [6,7].

It is known that besides causing various impacts on the life of an elderly person, the consequences of falls generate an increase of costs due to a greater need for use of specialized services and an increase in hospital admissions [4]. In 2011 , the falls represented $38.4 \%$ of the total external causes that had taken to hospitalization, reaching almost 20 hospital admissions by 10 thousand inhabitants [8].

Less serious falls that do not lead to death and institutionalization may, however, affect the health-related quality of life (HRQL) of the elderly person. The quality of life can be understood under two aspects: overall quality of life, where more objective factors of life are considered, such as income and housing conditions, and health-related quality of life (HRQL), where the impact that illness or health disorders have on people's lives are considered $[9,10]$.

An important instrument for measuring the HRQL and the self-referred health status is The Medical Outcomes Study 36-Item Short-Form Health Survey (SF-36), much used internationally, consisting of 36 items, divided into eight domains: functional capacity, physical aspects, pain, general state of health, vitality, social aspects, emotional aspects and mental health [11].

Studies indicate that the HRQL differs according to gender, age, socioeconomic factors, the number of chronic diseases and health problems [12-14]. However, it is unknown if there are population-based surveys, on the impact of falls in the several dimensions of the quality of life in elderly people' health, using SF-36 in Brazil.

Internationally, the studies are also scarce. A few of them use data from institutionalized subjects or specific to a group. In Oklahoma (USA), researchers studied the impact of falls in obese adults and found the lowest scores of the SF-36 in social aspects, pain, functional capacity and physical aspects for those individuals with reported recurrent falls in the past year [15]. Another study carried out in Canada, which evaluated the impact of falls through the SF-36 in elderly patients with chronic obstructive pulmonary disease (COPD), has found that those who had experienced one or more falls in the previous year had lower scores in all domains of the instrument [16].

In Brazil, Ribeiro et al. [2], using the WHOQOL-Bref (abbreviated Quality of Life Scale of the Worldwide Health Organization), studied 72 elderly of a low-income community in Rio de Janeiro city, who had suffered one or more falls in the last 12 months preceding the survey and found a reduction in the average of all scale domains.

The increase of healthy life years and quality of life is currently considered one of the main challenges for health promotion for elderly [17]. Thus, it is necessary to know the impact of health problems on the functional ability, in the social life and in the well-being of the elderly.
The study aims to identify the association between the occurrence of falls in last year and the domains of HRQL, assessed by the SF-36, by gender, age and education, in the elderly in Campinas/SP.

\section{MATERIALS AND METHODS}

It is a cross-sectional population-based study, where data from 1.432 elderly were analyzed (60 years old and over) non-institutionalized, residents in Campinas city urban areas. Data are from the Health Survey (ISACAMP 2008) aimed to obtain information from various health dimensions, from three age groups: adolescents (10-19 years), adults ( $20-59$ years) and elderly ( 60 years).

The number of people to comprise the sample of each domain was established considering $50 \%$ of proportion estimate with a confidence interval of $95 \%$, sampling error between 4 and 5 percentage points and a design effect of 2 . Thus, a minimum number of 1.000 interviews were established for each age domain.

The survey sample was obtained by probability sampling procedures, by cluster in two stages: census tracts and households. In the first stage, 50 census tracts were drawn with probability proportional to size (number of households). In the second stage, to achieve the required sample size, were drawn independently $2.150,700$ and 3.900 households to obtain the desired minimum number of adolescents, adults and elderly, respectively.

The information was obtained through a structured questionnaire, applied by trained and supervised interviewers. In this study, only the survey data relating to persons aged 60 or more were used.

The dependent variables of the study were the SF-36, version 2 eight scales (Physical functioning, Role physical, Body pain, General Health, Vitality, Role emotion, Social Functioning and Mental Health). The result of the scales is presented as a final score ranging from 0 through 100 , where 0 (zero) is the worst and 100 is the best state of health $[11,18,19]$.

The SF-36 was translated and validated into the Portuguese language by Ciconelli et al. (1999) [20]. The construction of scales scores and components of the SF-36 was conducted according to guidelines from the instructions manual of the instrument [19].

The main independent variables of the study were: occurrence of fall reported as main accident in the last 12 months, and reference of this fall with or without limitation of usual activities. Gender, age group (60 to 74 years and 75 years or more) and education (schooling average), were the covariates of the study and together with the referred number of comorbidities $(0,1-2,3$ or more) were also used in the analyzes adjustments.

The survey data were entered into a database developed using the software EpiData 3.1 (Epidata Association, Odense, Denmark) and submitted for consistency evalua- 
tion. The means and confidence intervals of $95 \%$ of the scales' scores and from the two components of the SF-36 were estimated, according to the occurrence of falls and according to falls which caused or not limitation of the usual activities.

Analyzes were conducted for the elderly population overall and stratified by gender, age group and education. For each scale and each component of the SF-36, and in each category of stratification a model of simple and multiple linear regression was carried through. All analyses had been conducted using software Stata 11.0 (Stata Corp, Station College, United States of America) using the svy commands incorporating the weightings resulting from the sample design.

The project of this study was approved by the Ethics Committee of the Faculty of Medical Sciences of the State University of Campinas, Brazil, in addendum to process no. $079 / 2007$.

\section{RESULTS}

Among the households selected to obtain the sample of elderly persons there was a loss of $14.2 \%$ due to the impossibility of knowing whether there was an elderly resident or not. Among the elderly identified in the selected households, there was $5.5 \%$ of refusal and $6.9 \%$ that were lost for other reasons. The elderly who were unable to directly respond the interview (96 elderly persons) due disability or dementia and whose information was given by family members or caregivers, were excluded from this study.

Although the survey addressed adolescents, adults and elderly, this study assessed only the information of individuals 60 years and older (60 to 74 years and 75 years or more). Thus 1.431 elderly persons were analyzed in this research.

From the studied sample 59.5\% were female, with average age of 69.9 years (CI 95\% 69.5 - 70.3). 69.6\% with less than eight years of education. $33.1 \%$ of the elderly reported having three or more chronic morbidities. 6.3\% reported the occurrence of falls in the last year, and out of these, 3.6\% reported having limitation of the habitual activities due to this fall (Table 1).

The mean scores of the SF-36 considering the total population (Table 2) were higher in the role emotional (87.3) and social functioning (83.3) and lower in vitality (72.1) and general health (72.1).

In relation to the total sample of elderly victims of fall in the last year, all SF-36 domains, except for the general health, showed significant associations $(p \leq 0.05)$ after adjustment by gender and age. It is observed that the total population of elderly male shows higher scores than females on all SF-36 scales. However, when analyzing the scores from men who had experienced fall they appear lower than females. When analyzing the difference in the scores of those who have experienced fall compared to those who did not, it is observed the largest differences in men than in women, showing the most affected domains, after adjustment with age and comorbidities: physical functioning, role physical, body pain and social functioning (Table 2).

In terms of age group (Table 3) it is observed that the elderly with 75 years or older, show lower scores on all SF-36 scales when compared to the elderly with 60 to 74 years. When analyzing the difference in the scores between those who experienced falls compared to those who did not, it is noted that the scales of role physical and social functioning, after adjustment with gender and comorbidities, remained with $\beta \geq-10$ and $\mathrm{p} \leq 0.05$ in those aged 75 years and over, while there was no association observed $(\mathrm{p} \leq 0.05)$ after this same adjustment, in the younger elderly group.

According to schooling years (Table 4) it is observed that those with less schooling ( 0 to 7 years), in the total sample, and those who had experienced fall showed lower scores on all SF-36 scales and significant association ( $\mathrm{p} \leq$ 0.05 ) after adjustment by gender, age and comorbidities, in role physical and social functioning. When analyzing the difference of association among those who had experienced fall compared to those who had not, the scale of social functioning was the most affected $(\beta \geq-10)$ in the less schooling group.

In the Table 5, it is observed that in the total elderly sample, those who reported limitation of usual activities due to the fall, showed lower scores on all SF-36 scales compared to those who did not experienced falls. The scales of physical functioning, role physical, body pain and social functioning were the most affected, even after adjustment by gender, age and comorbidities. No differences were found between those who reported falls without limitation and those who did not fall.

\section{DISCUSSION}

The study shows that the elderly who had experienced falls in the year prior to the interview showed significantly lower scores compared to those who did not fall, with seven of the eight SF-36 scales, after the adjustment by gender and age. It must be observed that the male population who had experienced falls last year and reported limitation of usual activities due to falls, showed worse HRQL, through lower SF-36 scores compared to females. The older elderly, aged 75 and more and the less schooled who had fallen last year, also showed lower SF-36 scores when compared to younger elderly and with higher schooling.

The scales that were more affected in the elderly who had experienced falls in the last 12 months prior to the survey were physical functioning, role physical and body pain. Results of a previously mentioned study, involving the population of obese adults in Oklahoma (USA), also 
Table1. Description of the study population second occurrence of falls in individuals 60 years and older. ISACAMP 2008.

\begin{tabular}{|c|c|c|c|c|}
\hline Variables & n (\%) & Occurrence of Fall & $\begin{array}{c}\text { Prevalence } \\
\text { Ratio (CI 95\%) }\end{array}$ & $\begin{array}{c}\text { Prevalence Ratio adjusted } \\
\text { (gender/age) }\end{array}$ \\
\hline Gender & & $0,0002^{*}$ & & \\
\hline Male & $579(40.5)$ & $3.3(2.1-5.1)$ & 1 & 1 \\
\hline Female & $852(59.5)$ & $8.4(6.8-10.5)$ & $2.54(1.55-4.15)$ & $2.39(1.48-3.86)$ \\
\hline Total & $1431(100)$ & $6.3(5.1-7.6)$ & & \\
\hline Age & & $0.0000^{*}$ & & \\
\hline $60-74$ & $1067(74.6)$ & $4.6(3.5-5.9)$ & 1 & 1 \\
\hline 75 and over & $364(25.4)$ & $11.2(8.2-14.9)$ & $2.42(1.64-3.56)$ & $2.30(1.60-3.32)$ \\
\hline Education (years) & & $0.2519^{*}$ & & \\
\hline $0-7$ & $996(69.6)$ & $6.8(5.4-8.6)$ & 1 & 1 \\
\hline 8 and over & $434(30.4)$ & $5.0(3.1-8.0)$ & $0.73(0.42-1.28)$ & $0.97(0.58-1.62)$ \\
\hline Number of chronic morbidities & & $0.0120^{*}$ & & \\
\hline 0 & $278(19.7)$ & $2.0(0.9-4.6)$ & 1 & 1 \\
\hline $1-2$ & $666(47.2)$ & $5.9(4.1-8.3)$ & $2.86(1.07-7.61)$ & $2.46(0.97-6.23)$ \\
\hline 3 or more & $467(33.1)$ & $8.5(5.9-12.1)$ & 4.12(1.55 - 10.94) & 2.93(1.15 - 7.47) \\
\hline${ }^{*} P$ value in the chi-square test & & & & \\
\hline
\end{tabular}

Table 2. Mean scores of the SF-36 seconds occurrence of fall and sex stratification in the elderly. ISACAMP 2008.

\begin{tabular}{|c|c|c|c|c|c|c|c|}
\hline \multirow{3}{*}{ Domains } & \multicolumn{3}{|c|}{ Mean Scores and CI(95\%) } & \multicolumn{2}{|c|}{$\begin{array}{l}\text { Analysis } \\
\text { Adjusted }^{* *}\end{array}$} & \multicolumn{2}{|c|}{ Analysis Adjusted $^{* * *}$} \\
\hline & \multirow{2}{*}{$\begin{array}{c}\text { Total } \\
\mathrm{n}=1431\end{array}$} & \multicolumn{2}{|c|}{ Falls } & \multirow[b]{2}{*}{$\beta$} & \multirow[b]{2}{*}{$\mathrm{p}$} & \multirow[b]{2}{*}{$\beta$} & \multirow[b]{2}{*}{$\mathrm{p}$} \\
\hline & & Yes $(n=91)$ & No $(n=1340)$ & & & & \\
\hline & & & Total & & & & \\
\hline Physical functioning & $75.1(72.9-77.3)$ & $61.9(56.2-67.6)$ & $76.0(73.7-78.2)$ & -8.7 & 0.003 & -6.5 & 0.031 \\
\hline Role physical & $78.6(76.4-80.9)$ & $66.4(59.6-73.2)$ & $79.4(77.2-81.7)$ & -9.4 & 0.004 & -6.7 & 0.027 \\
\hline Body Pain & $75.4(73.7-77.1)$ & $64.1(56.6-71.6)$ & $76.2(74.6-77.8)$ & -8.7 & 0.031 & -6.7 & 0.096 \\
\hline General Health & $72.1(70.1-74.1)$ & $70.3(65.3-75.3)$ & $72.2(70.3-74.1)$ & -0.9 & 0.659 & 1.1 & 0.574 \\
\hline Vitality & $72.1(69.5-74.8)$ & $64.8(60.1-69.6)$ & $72.6(69.9-75.4)$ & -5.8 & 0.016 & -3.8 & 0.106 \\
\hline Role Emotion & $87.3(85.6-88.9)$ & $79.1(73.1-85.0)$ & $87.8(86.2-89.5)$ & -6.1 & 0.046 & -3.7 & 0.130 \\
\hline Social Functioning & $83.3(81.1-85.5)$ & $72.5(66.8-78.3)$ & $84.0(81.7-86.2)$ & -8.9 & 0.002 & -7.9 & 0.004 \\
\hline \multirow[t]{3}{*}{ Mental Health } & 77.6(75.6 - 79.6) & $71.5(67.0-76.1)$ & $78.1(76.1-80.1)$ & -5.3 & 0.029 & -3.7 & 0.151 \\
\hline & & & Male & & & & \\
\hline & $\mathrm{n}=579$ & $\mathrm{n}=19$ & $\mathrm{n}=560$ & & & & \\
\hline Physical functioning & $80.1(77.1-83.0)$ & $51.8(36.7-66.9)$ & $81.0(78.2-83.9)$ & -26.1 & 0.000 & -22.4 & 0.000 \\
\hline Role physical & $81.1(78.1-84.1)$ & $52.7(35.6-69.8)$ & $82.1(79.1-85.0)$ & -26.8 & 0.001 & -23.2 & 0.001 \\
\hline Body Pain & $80.6(78.4-82.8)$ & $59.1(40.5-77.6)$ & $81.4(79.4-83.4)$ & -20.6 & 0.013 & -19.3 & 0.029 \\
\hline General Health & $73.2(71.0-75.4)$ & $66.0(57.2-74.9)$ & $73.5(71.3-75.6)$ & -6.7 & 0.094 & -4.2 & 0.253 \\
\hline Vitality & $75.4(72.5-78.4)$ & $67.3(54.9-79.7)$ & $75.7(72.8-78.6)$ & -7.4 & 0.163 & -4.9 & 0.349 \\
\hline Role Emotion & $89.9(87.8-92.0)$ & $76.5(59.6-93.4)$ & $90.3(88.3-92.4)$ & -12.8 & 0.095 & -8.0 & 0.175 \\
\hline Social Functioning & $85.5(82.7-88.2)$ & $60.1(43.8-76.4)$ & $86.4(83.8-88.9)$ & -24.9 & 0.001 & -21.8 & 0.002 \\
\hline \multirow[t]{3}{*}{ Mental Health } & $80.2(78.0-82.4)$ & $70.6(59.9-81.2)$ & $80.6(78.4-82.8)$ & -9.2 & 0.054 & -7.8 & 0.122 \\
\hline & & & Female & & & & \\
\hline & $\mathrm{n}=852$ & $\mathrm{n}=72$ & $\mathrm{n}=780$ & & & & \\
\hline Physical functioning & $71.4(68.6-74.2)$ & $64.9(58.5-71.3)$ & $72.0(69.0-75.0)$ & -3.1 & 0.349 & -1.5 & 0.680 \\
\hline Role physical & $76.8(74.0$ - 79.6) & $70.4(63.3-77.6)$ & $77.4(74.5-80.3)$ & -3.8 & 0.272 & -1.6 & 0.665 \\
\hline Body Pain & $71.5(69.3-73.8)$ & $65.6(58.2-73.0)$ & $72.1(69.8-74.4)$ & -4.9 & 0.204 & -2.4 & 0.521 \\
\hline General Health & $71.3(69.2-73.4)$ & $71.6(66.1-77.1)$ & $71.2(69.1-73.3)$ & 0.8 & 0.736 & 2.6 & 0.278 \\
\hline Vitality & $69.7(66.8-72.6)$ & $64.1(58.8-69.3)$ & $70.2(67.2-73.2)$ & -5.4 & 0.040 & -3.4 & 0.175 \\
\hline Role Emotion & $85.4(83.2-87.6)$ & $79.8(73.7-86.0)$ & $85.9(83.6-88.2)$ & -3.8 & 0.243 & -2.3 & 0.439 \\
\hline Social Functioning & $81.6(78.9-84.3)$ & $76.2(70.7-81.7)$ & $82.1(79.3-85.0)$ & -3.8 & 0.208 & -3.4 & 0.227 \\
\hline Mental Health & $75.7(73.5-78.0)$ & $71.8(67.0-76.6)$ & 76.1(73.8 - 78.4) & -4.3 & 0.085 & -2.5 & 0.334 \\
\hline
\end{tabular}

${ }^{* *}$ Beta coefficients: estimated by multiple linear regression, with adjustment for age and/or gender; ${ }^{* * *}$ Beta coefficients estimated by multiple linear regression, with adjustment for age and / or gender and comorbidities. 
Table 3. Mean scores of the SF-36 according to the occurrence of falls and stratification by age in the elderly. ISACAMP 2008.

\begin{tabular}{|c|c|c|c|c|c|c|c|}
\hline \multirow{3}{*}{ Domains } & \multicolumn{3}{|c|}{ Mean Scores and CI(95\%) } & \multirow{2}{*}{\multicolumn{2}{|c|}{ Analysis Adjusted ${ }^{* *}$}} & \multirow{2}{*}{\multicolumn{2}{|c|}{ Analysis Adjusted $^{* * *}$}} \\
\hline & \multirow{2}{*}{$\begin{array}{c}\text { Total } \\
\mathrm{n}=1431\end{array}$} & \multicolumn{2}{|c|}{ Falls } & & & & \\
\hline & & Yes $(n=91)$ & No $(n=1340)$ & $\beta$ & $\mathrm{p}$ & $\beta$ & $\mathrm{p}$ \\
\hline & & & $60-74$ & & & & \\
\hline & $\mathrm{N}=1067$ & Yes $(\mathrm{n}=50)$ & No $(n=1017)$ & & & & \\
\hline Physical functioning & $79.2(76.9-81.4)$ & $69.8(61.9-77.8)$ & $79.6(77.5-81.8)$ & -8.4 & 0.033 & -4.6 & 0.244 \\
\hline Role physical & $81.9(79.6-84.1)$ & $74.2(66.3-82.2)$ & $82.3(80.0-84.5)$ & -7.6 & 0.048 & -3.4 & 0.334 \\
\hline Body Pain & $77.1(75.3-78.8)$ & $64.2(54.9-73.5)$ & $77.7(75.9-79.4)$ & -11.8 & 0.018 & -7.8 & 0.116 \\
\hline General Health & $72.5(70.4-74.6)$ & $71.7(65.3-78.2)$ & $72.5(70.5-74.5)$ & -0.4 & 0.891 & 3.5 & 0.216 \\
\hline Vitality & $73.1(70.3-75.8)$ & $66.2(59.6-72.6)$ & $73.4(70.6-76.2)$ & -6.1 & 0.070 & -2.7 & 0.343 \\
\hline Role Emotion & $89.2(87.5-90.9)$ & $84.3(77.1-91.6)$ & $89.5(87.8-91.2)$ & -4.7 & 0.185 & -0.5 & 0.830 \\
\hline Social Functioning & $85.5(83.2-87.8)$ & $80.5(73.3-87.7)$ & $85.7(83.5-88.0)$ & -4.8 & 0.142 & -2.7 & 0.365 \\
\hline \multirow[t]{3}{*}{ Mental Health } & $77.9(75.1-80.1)$ & $70.7(64.7-76.8)$ & $78.2(76.0-80.4)$ & -6.5 & 0.032 & -3.3 & 0.273 \\
\hline & & & 75 or older & & & & \\
\hline & $\mathrm{n}=364$ & Yes $(n=41)$ & No $(\mathrm{n}=323)$ & & & & \\
\hline Physical functioning & $63.3(59.5-67.1)$ & $52.4(44.1-60.8)$ & $64.6(60.7-68.6)$ & -10.2 & 0.028 & -9.2 & 0.066 \\
\hline Role physical & $69.2(65.3-73.1)$ & $57.0(46.7-67.3)$ & $70.7(66.8-74.6)$ & -12.4 & 0.019 & -10.8 & 0.038 \\
\hline Body Pain & $70.6(67.4-73.9)$ & $64.1(52.7-75.4)$ & $71.5(68.1-74.8)$ & -5.6 & 0.334 & -5.6 & 0.351 \\
\hline General Health & $70.9(67.9-73.8)$ & $68.6(61.8-75.4)$ & $71.2(68.4-73.9)$ & -2.3 & 0.415 & -2.0 & 0.481 \\
\hline Vitality & $69.5(66.0-73.0)$ & $63.2(56.9-69.5)$ & $70.3(66.8-73.7)$ & -6.3 & 0.044 & -5.5 & 0.111 \\
\hline Role Emotion & $81.6(78.6-84.7)$ & $72.7(64.0-81.4)$ & $82.8(79.7-85.9)$ & -8.1 & 0.087 & -7.5 & 0.121 \\
\hline Social Functioning & $76.7(72.9-80.5)$ & $62.9(53.7-72.2)$ & $78.5(74.7-82.2)$ & -14.2 & 0.004 & -14.1 & 0.006 \\
\hline Mental Health & $76.9(74.1-79.7)$ & $72.5(65.6-79.4)$ & $77.5(74.6-80.3)$ & -4.5 & 0.225 & -4.5 & 0.240 \\
\hline
\end{tabular}

${ }^{* *}$ Beta coefficients estimated by the multiple linear regression, with adjustment for gender. ${ }^{* * *}$ Beta coefficients estimated by the multiple linear regression, with adjustment for gender and comorbidities.

Table 4. Mean scores of the SF-36 according to the occurrence of falls and educational stratification in the elderly. ISACAMP 2008.

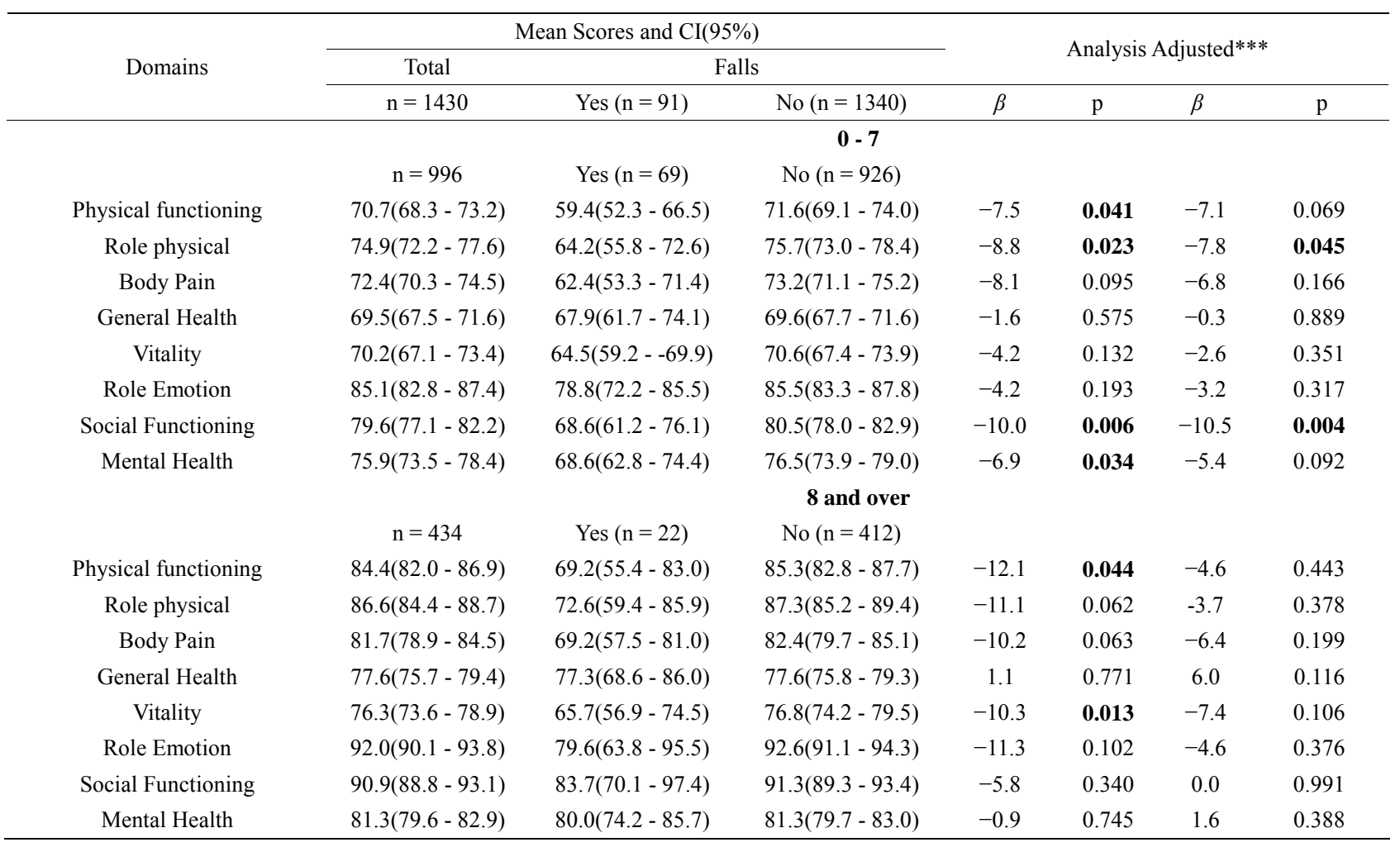

${ }^{* * *}$ Beta coefficients estimated by multiple linear regression, with adjustment for gender, age and comorbidities. 
Table 5. Mean scores of the SF-36 seconds occurrence of fall, with and without limitations of usual activities. ISACAMP 2008.

\begin{tabular}{|c|c|c|c|c|c|c|c|c|c|c|c|}
\hline \multirow{3}{*}{ Domains } & \multicolumn{3}{|c|}{ Mean Scores and $\mathrm{CI}(95 \%)$} & \multicolumn{4}{|c|}{ Analysis Adjusted $^{* *}$} & \multicolumn{4}{|c|}{ Analysis Adjusted $^{* * *}$} \\
\hline & \multirow{2}{*}{$\begin{array}{l}\text { Not suffered } \\
\text { falls } \\
(0)\end{array}$} & \multicolumn{2}{|c|}{ Suffered falls $(n=91)$} & \multirow[b]{2}{*}{$\begin{array}{c}\beta \\
(2-0)\end{array}$} & \multirow[b]{2}{*}{$\mathrm{p}$} & \multirow[b]{2}{*}{$\begin{array}{c}\beta \\
(1-0)\end{array}$} & \multirow[b]{2}{*}{$\mathrm{p}$} & \multirow[b]{2}{*}{$\begin{array}{c}\beta \\
(2-0)\end{array}$} & \multirow[b]{2}{*}{$\mathrm{p}$} & \multirow[b]{2}{*}{$\begin{array}{c}\beta \\
(1-0)\end{array}$} & \multirow[b]{2}{*}{$P$} \\
\hline & & $\begin{array}{l}\text { with limited } \\
\text { (2) }\end{array}$ & $\begin{array}{l}\text { without limitation } \\
\text { (1) }\end{array}$ & & & & & & & & \\
\hline & $\mathrm{n}=1340$ & $\mathrm{n}=52$ & $\mathrm{n}=39$ & & & & & & & & \\
\hline Physical functioning & $76.3(74.0-78.5)$ & $54.6(46.3-63.0)$ & $71.5(62.6-80.5)$ & -15.1 & 0.000 & -0.7 & 0.862 & -11.7 & 0.007 & -0.0 & 0.987 \\
\hline Role physical & $80.0(77.8-82.3)$ & $58.0(50.2-65.8)$ & $77.5(68.3-86.7)$ & -17.2 & 0.000 & 0.1 & 0.980 & -13.5 & 0.000 & 1.4 & 0.728 \\
\hline Body Pain & $76.8(75.1-78.4)$ & $59.8(50.0-69.5)$ & $69.9(61.3-78.5)$ & -12.4 & 0.016 & -4.0 & 0.329 & -10.0 & 0.059 & -2.6 & 0.540 \\
\hline General Health & $72.2(70.3-74.2)$ & $67.4(62.6-72.2)$ & $74.2(66.1-82.3)$ & -3.6 & 0.125 & 2.5 & 0.459 & -0.7 & 0.750 & 3.6 & 0.293 \\
\hline Vitality & $72.7(70.0-75.4)$ & $63.3(57.5-69.1)$ & $66.9(60.4-73.3)$ & -7.1 & 0.018 & -4.3 & 0.156 & -5.0 & 0.104 & -2.3 & 0.445 \\
\hline Role Emotion & $88.2(86.5-89.8)$ & $71.9(63.4-80.5)$ & $88.4(82.4-94.4)$ & -12.7 & 0.005 & 2.3 & 0.425 & -9.6 & 0.014 & 3.5 & 0.184 \\
\hline Social Functioning & $84.5(82.2-86.8)$ & $66.9(58.4-75.4)$ & $79.9(71.3-88.6)$ & -14.0 & 0.002 & -2.8 & 0.466 & -12.3 & 0.006 & -2.6 & 0.493 \\
\hline Mental Health & $78.2(76.2-80.2)$ & $71.1(65.3-77.0)$ & $72.1(66.0-78.1)$ & -5.6 & 0.064 & -5.1 & 0.084 & -3.8 & 0.238 & -3.6 & 0.222 \\
\hline
\end{tabular}

${ }^{* *}$ Beta coefficients estimated by the multiple linear regression, with adjustment for age and/or gender. ${ }^{* * *}$ Beta coefficients estimated by the multiple linear regression, with adjustment for comorbidities, age and/or gender.

indicated the lowest scores of the SF-36 in physical and social aspects, pain and functional capacity in individuals with a history of falls [15]. Another study conducted in Brazil with 120 elderly subjects, using the WHOQOL, also found that the presence of falls in the past six months was associated with the worst condition in the physical domain assessed by the instrument [21]. Fabricio et al (2004), in the study with elderly residents of Ribeirão Preto/SP, confirmed that the consequences generated by the falls lead to an increase in the functional dependence for carrying out activities of daily life (ADLs) [22].

According to the International Classification of Functioning, Disability and Health of the World Health Organization (ICF), the functional capacity can be understood by the execution of tasks or actions under the competence of the organism and environmental conditions, i.e., there is a relationship between the ability of the individual to adjust his needs to the environment in which he lives [23]. The disabilities are worthy of attention because they cause the dependency for carrying out tasks and decreased autonomy of the subjects [24], who tend to live under the care of other people.

The body pain has also been associated with the occurrence of falls. This is another important issue considering the health and well-being of the elderly, since that the pain can cause depression and decreased vitality and compromise its physical functioning, generating loss of autonomy and damages in the lives of individuals and families [25].

In this study, despite the fact that the falls have occurred more frequently in females, the damages related to this occurrence were greater in males, being observed with a strong association with the physical dimension of health, especially in the scales of physical functioning, role physical, body pain and social functioning. However, this result differs from the work of Stel et al. (2004) who analyzed the consequences of falls in a sub sample of elderly of the study LASA (Longitudinal Aging Study Amsterdam). The authors found that the impact of falls in the decline of functionality had been greater for the females [26].

No studies that have addressed this finding of the greater impact of falls for the males were found. However, it may be noted that the elderly males who had experienced falls are those who are in worse HRQL conditions, especially in the physical aspects, although they have made another assessment of their own health.

Research results indicate that women consider themselves in worse health conditions than men [12,27]. This could justify the absence of decline in the SF-36 scales in this population. Fried et al. (2000) by means of a longitudinal study of seven years, with the objective to develop and put into operation a syndromic profile for frailty in elderly people, show that the likelihood of becoming frail is high among women. These authors argue that women could offer an increased risk of fragility by the fact that the amount of lean mass and muscle strength is lower than men of the same age. In addition, women could also be more exposed to extrinsic factors that cause sarcopenia, such as the inadequate dietary intake compared to men [28].

In relation to age, an attention is drawn to the problem of falls as one becomes older. The biological aging process involves structural and functional changes that accumulate progressively with increasing age [29]. As time goes by in one's life, there is a decrease of the muscle strength and elasticity, loss of stability and joint dynamics, alterations in the sensory, vestibular and somatosensory and nervous system. These changes imply the commitment of the postural control mechanisms, changing posture, gait and balance which may increase the predisposition to falls $[3,19,29,30]$.

In relation to educational level, it was observed that the 
falls are negatively associated with the HRQL for those with low educational level. No studies have been found to evaluate the association of falls with the HRQL using the SF-36, according to age and level of education for comparison with these results. However, researches confirmed that the prevalence of falls is greater in elderly with lower schooling levels [5,31]. The physical and social role functions were most affected in this population. It is worth noting that the role physical assesses the impact of physical health problems in daily activities and/or work. These aspects should be carefully considered, given, for example, the importance of work in elderly person's life, including helping to engage in social activities [32,33]. And in the case of elderly with lower socioeconomic strata, the difficulties at work will also compromise the elderly's income.

Another negative association found was the limitation of usual activities as a result of the falls and HRQL, being the scales of physical function, role physical, role emotional and social functioning the most affected. Lopes and Dias (2010), in a literature review, mentioned some consequences caused by falls, which in turn comes to solidify the association found in this study. Among them are the limitation of mobility and dependence in performing basic and instrumental activities of daily life [34]. Studies on this subject are scarce in Brazil and in other countries, especially considering the association of the occurrence of the falls with the SF-36 scales in population-based areas, making it difficult to compare between researches.

One limitation of the study is that the cross-sectional design does not allow inferences about causality of the association. It is possible that the elderly who are in poorer health conditions and quality of life are those who are most vulnerable to falls. On the other hand, we must emphasize that the quality of life has been jeopardized due to the occurrence of falls, i.e., they can have negative consequences for the life and health of the subject. In this sense, it is important to consider that the results presented indicate only associations.

The results of this study make a warning to caregivers and health care programs for the elderly for two perspectives in relation to the occurrence of falls: on the one hand, they lead to important limitations to the elderly, which are associated with worse health condition and quality of life, through losses primarily in the domains of physical function, role physical and body pain. On the other hand, it is worth considering that the impaired elderly, especially in physical functioning, role physical, body pains and with difficulty in normal social relationships, are more vulnerable to experiencing falls, including the most serious falls, which cause limitations. The study also points out that the elderly males, more advanced in age and less schooled, deserve special attentions in relation to falls because it is shown that they are more greatly damaged in most scales assessed by the SF-36.

Given the scarcity of studies in this topic in non-institutionalized elderly in Brazil and internationally, the study points to the need for the further research and contributes to the advancement of knowledge, providing the information for health policies directed to the elderly population.

\section{REFERENCES}

[1] Wong, L.L.R. and Carvalho, J.A. (2006) O rápido processo de Envelhecimento populacional do Brasil: Sérios desafios para as políticas públicas. Revista Brasileira de Estudos Populacionais, 23. http://dx.doi.org/10.1590/S0102-30982006000100002

[2] Ribeiro, A.P., Souza, E.R., Atie, S., Souza, A.C. and Schilithz, A.D. (2008) A influência das quedas na qualidade de vida de idosos. Ciência \& Saude Coletiva, 13, 12651273.

http://dx.doi.org/10.1590/S1413-81232008000400023

[3] Cunha, U.G. and Guimarães, R.M. (1989) Sinais e sintomas do aparelho locomotor. In: Guimarães, R.M., Cunha, U.G. Sinais e Sintomas em Geriatria, Rio de Janeiro, Revinter, 141-154.

[4] Perracini, M.R. and Ramos, L.R. (2002) Fatores associados a quedas em uma coorte de idosos residentes na comunidade. Revista de Saúde Pública, 36, 709-716. http://dx.doi.org/10.1590/S0034-89102002000700008

[5] Siqueira, F.V., Facchini, L.A., Piccini, R.X., Tomasi, E, Thumé, E, Silveira, D.S, et al. (2007) Prevalência de quedas em idosos e fatores associados. Revista de Saúde Pública, 41, 749-756. http://dx.doi.org/10.1590/S0034-89102007000500009

[6] Tinetti, M.E. and Kumar, C. (2010) The patient who falls. JAMA, 303, 258-266. http://dx.doi.org/10.1001/jama.2009.2024

[7] Deandrea, S., Lucenteforte, E., Bravi, F., Foschi, R., La Vecchia, C. and Negri, E. (2010) Risk factors for falls in community-dwelling older people: A systematic review and meta-analysis. Epidemiology, 21, 658-668. http://dx.doi.org/10.1097/EDE.0b013e3181e89905

[8] Brasil (2012) Ministério da Saúde. Secretaria de Vigilância em Saúde. Departamento de Análise de Situação em Saúde. Saúde Brasil 2011: Morbidade por acidentes e violências no Brasil: Tendência das hospitalizações no período de 2002 a 2011/Ministério da Saúde, Secretaria de Vigilância em Saúde, Departamento de Análise de Situação em Saúde. Ministério da Saúde, Brasília.

[9] Minayo, M.C.S., Hartz, Z.M.A. and Buss, P.M. (2000) Qualidade de vida e saúde: Um debate necessário. Cien Saude Coletiva, 5, 7-18. http://dx.doi.org/10.1590/S1413-81232000000100002

[10] Seidl, E.M.F. and Zannon, C.M.L.C. (2004) Qualidade de vida e saúde: Aspectos conceituais e metodológicos. $\mathrm{Ca}$ dernos de Saúde Pública, 20, 580-588. http://dx.doi.org/10.1590/S0102-311X2004000200027

[11] Ware, J.E., Kosinski, M., Dewey, J.E. and Gandek, B. 
(2000) SF-36 health survey: Manual and interpretation guide. Quality Metric Inc., Lincoln.

[12] Lima, M.G., Barros, M.B.A., Cesar, C.L.G., Goldbaum, M., Carandina, L. and Cicconeli, R.M. (2009) Impact of chronic disease on quality of life among the elderly in the state of São Paulo, Brazil: A population-based study. Revista Panamericana de Salud Pública, 25. http://dx.doi.org/10.1590/S1020-49892009000400005

[13] Lima, M.G., Barros, M.B.A., Cesar, C.L.G., Goldbaum, M., Carandina, L. and Cicconeli, R.M. (2009) Health related quality of life among the elderly: A populationbased study using SF-36 survey. Cadernos de Saúde Pública, 25, 2159-2167.

http://dx.doi.org/10.1590/S0102-311X2009001000007

[14] Lima, M.G., Barros, M.B.A., César, C.L.G., Goldbaum, M., Carandina, L. and Alves, M.C.G.P. (2011) Comportamentos relacionados à saúde e qualidade de vida em idosos: Um estudo de base populacional. Revista de Saúde Pública, 45, 485-493. http://dx.doi.org/10.1590/S0034-89102011000300006

[15] Fjelstad, C., Fjeldstad, A.S., Acree, L.S., Nickel, K.J. and Garner, A.W. (2008) The influence of obesity on falls and quality of life. Dynamic Medicine, 7, 4. http://dx.doi.org/10.1186/1476-5918-7-4

[16] Roig, M., Eng, J. J., MacIntyre, D. L., Fitz Gerald, J.M., Burns, J. and Reid, W. D. (2011) Falls in people with chronic obstructive pulmonary disease: An observational cohort study. Respiratory Medicine, 105, 461-469. http://dx.doi.org/10.1016/j.rmed.2010.08.015

[17] Fleck, M.P.A., Chachamovich, E. and Trentini, C.M. (2003) WHOQOL-OLD Project method and focus group results in Brazil. Revista de Saúde Pública, 37, 793-799. http://dx.doi.org/10.1590/S0034-89102003000600016

[18] Campolina, A.G. and Ciconelli, R.M. (2008) O SF-36 e o desenvolvimento de novas medidas de avaliação da qualidade de vida. Acta Reumatológica Portuguesa, 33, 127-133.

[19] Ciconelli, R.M., Ferraz, M.B. and Santos, W. (1999) Tradução para a língua portuguesa e validação do questionário genérico de avaliação de qualidade de vida SF-36 (Brasil SF-36). Revista Brasileira de Reumatologia, 39, 143-150.

[20] Ware, J.E., Kosinski, M., Bjorner, J.B., Turner-Bowker, D.M. and Maruish, M.E. (2007) User's manual for the SF-36 ${ }^{\circledR}$ health survey (version 2).

[21] Da Silva, A., Cordeiro, T., Cereda, R. and Ramos, L.R. (2009) Fatores associados à qualidade de vida em idosos ativos. Revista de Saúde Pública, 43, 613-621.

[22] Fabrício, S.C.C., Rodrigues, R.A.P. and Costa Junior, M.L. (2004) Causas e consequências de quedas de idosos atendidos em hospital público. Revista de Saúde Pública, 38, 93-99.

http://dx.doi.org/10.1590/S0034-89102004000100013
[23] Organização Mundial de Saúde (OMS)/Organização Panamericana de Saúde (OPAS) (2003) CIF classificação internacional de funcionalidade, incapacidade e saúde. Universidade de São Paulo.

[24] Lima-Costa, M.F., Sandhi, M.B. and Giatti, L. (2003) Condições de saúde, capacidade funcional, uso de serviços de saúde e gastos com medicamentos da população idosa brasileira: um estudo descritivo baseado na Pesquisa Nacional por Amostra de Domicílios. Cadernos de Saúde Pública, 19, 735-743. http://dx.doi.org/10.1590/S0102-311X2003000300006

[25] Dellarozza, M.S.G., Pimenta, C.A.M., Matsuo, T. (2007) Prevalência e caracterização da dor crônica em idosos não institucionalizados. Cadernos de Saúde Pública, 23, $1151-1160$. http://dx.doi.org/10.1590/S0102-311X2007000500017

[26] Stel, V. S., Smit, J.H., Pluijm, S.M. and Lips, P. (2004) Consequences of falling in older men and women and risk factors for health service use and functional decline. Age and Ageing, 33, 58-65.

http://dx.doi.org/10.1093/ageing/afh028

[27] Barros, M.B.A., Cesar, C.L.G., Carandina, L. and Torre, G.D. (2006) Desigualdades sociais na prevalência de doenças crônicas no Brasil, PNAD-2003. Ciênc Saúde Coletiva, 11, 911-926.

http://dx.doi.org/10.1590/S1413-81232006000400014

[28] Fried, L.P., Bandeen-Roche, K., Chaves, P.H. and Johnson, B.A. (2000) Preclinical mobility disability predicts incident mobility disability in older women. The Journals of Gerontology Series A, 55A, M43-M52.

[29] Cruz, D.T., Ribeiro, L.C., Vieira, M.T., et al. (2012) Prevalência de quedas e fatores associados em idosos. Revista de Saúde Pública, 46, 138-146. http://dx.doi.org/10.1590/S0034-89102011005000087

[30] Agostinho, C.S. and Máximo, G.C. (2006) Idosos num Brasil que envelhece: Uma análise multidimensional da pobreza. Trabalho apresentado no XV Encontro Nacional de Estudos Populacionais, 18-22 set, ABEP, Caxambu.

[31] Jahana, K.O. and Diogo, M.J.D.E. (2007) Quedas em idosos: Principais causas e consequências. Saúde Coletiva, 4, 148-153.

[32] Veras, R.P., Ramos, L.R. and Kalache, A. (1987) Crescimento da população idosa no Brasil: Transformações e consequências na sociedade. Revista de Saúde Pública, 21, 225-233. http://dx.doi.org/10.1590/S0034-89101987000300007

[33] Deps, V.L. (2007) Atividade e bem-estar psicológico na maturidade. In: Neri, A.L., Org., Qualidade de Vida e Idade Madura, $7^{\mathrm{a}}$. Edition, Campinas, Papirus, 57-82.

[34] Dias, R.C. and Lopes, R.A. (2010) O impacto das quedas na qualidade de vida dos idosos. ComScientiae Saúde, $\mathbf{9}$, 504-509. 


\section{ABREVIATIONS}

HRQL: Health Related Quality of Life

SF-36: The Medical Outcomes Study 36-Item ShortForm Health Survey

ISACAMP 2008: Campinas Health Survey-2008

WHO: World Health Organization

USA: United States of America
WHOQOL: Bref-Abbreviated Quality of Life Scale of the Worldwide Health Organization

COPD: Chronic Obstructive Pulmonary Disease CI 95\%: Confidential Interval of $95 \%$

ADLs: Activities of Daily Life

ICF: International Classification of Functioning

LASA: Longitudinal Aging Study Amsterdam 